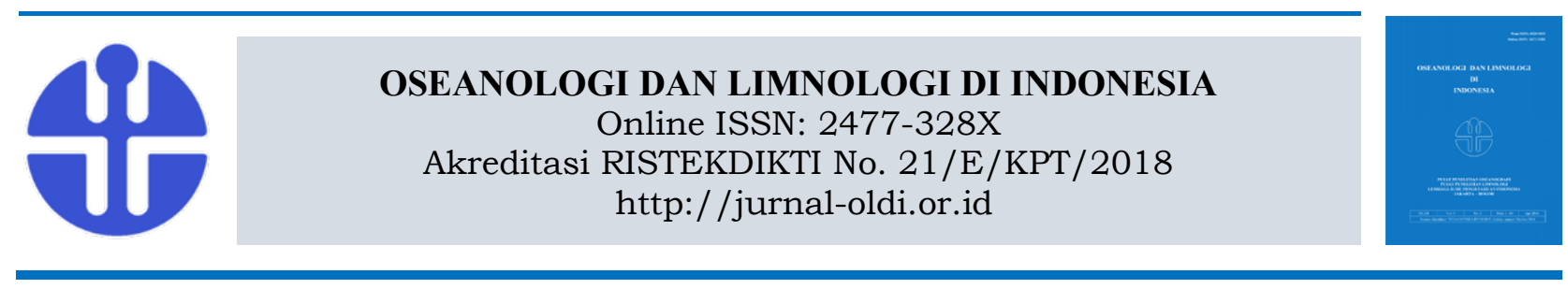

\title{
Sumberdaya Kuda Laut (Hippocampus spp.) di Perairan Pulau Bintan, Teluk Lampung dan Pulau Tanakeke
}

\author{
Masayu Rahmia Anwar Putri, Astri Suryandari dan Joni Haryadi \\ Balai Riset Pemulihan Sumberdaya Ikan \\ Email : masayurahmia33@gmail.com
}

Submitted 13 February 2018. Reviewed 10 December 2018. Accepted 11 February 2019

DOI: 10.14203/oldi.2019.v4i1.194

\begin{abstract}
Abstrak
Informasi tentang sumberdaya kuda laut sangat terbatas, dari 35 jenis kuda laut di dunia yang terdaftar dalam IUCN redlist, 20 jenis terdaftar sebagai "data deficient" yang menggambarkan kurangnya informasi terkait kuda laut, bahkan untuk jenis yang sangat tereksploitasi. Penelitian ini dilakukan untuk menginventarisir sumberdaya kuda laut (Hippocampus spp.) meliputi informasi jenis, ukuran, nisbah kelamin dan kepadatan kuda laut dari tiga lokasi potensial, yaitu perairan Pulau Bintan, Teluk Lampung dan Pulau Tanakeke. Observasi lapangan dilakukan pada tahun 2016 dengan metode purposive sampling, wawancara dengan para nelayan dan pengepul kuda laut serta studi pustaka. Hasil penelitian menunjukkan adanya perbedaan sumberdaya kuda laut yang ditemukan di ketiga lokasi penelitian. Jenis kuda laut paling banyak ditemukan di perairan Bintan, sebanyak empat jenis (H. comes, $H$. spinossisimus, $H$. hystrix, dan $H$. $k u d a)$, diikuti Teluk Lampung dua jenis ( $H$. comes dan $H$. kuda) dan di perairan Tanakeke hanya ditemukan satu jenis ( $H$. barbouri). Sebagian besar kuda laut yang ditemukan selama penelitian dikategorikan sudah matang secara seksual dimana kuda laut yang mendominasi berukuran 11-12 cm. Jenis dan kepadatan kuda laut yang berbeda di ketiga lokasi penelitian didukung oleh perbedaan habitat dimana kuda laut ditemukan. Kepadatan kuda laut di ketiga lokasi penelitian cenderung rendah akibat eksploitasi yang berlebihan, perubahan lingkungan dan kerusakan habitat. Langkah pengelolaan berbasis aspek biologi dan kondisi ekologi dari masing-masing wilayah perlu dilakukan untuk perikanan kuda laut yang berkelanjutan.
\end{abstract}

Kata kunci: Kuda laut, Hippocampus spp., Pulau Bintan, Teluk Lampung, Pulau Tanakeke

\begin{abstract}
Seahorse Resources (Hippocampus spp.) in the Waters of Bintan Island, Lampung Bay and Tanakeke Island. Information on seahorse resources is very limited, from 35 species of marine species listed on the IUCN redlist, 20 species are listed as "data deficient" which illustrates the lack of information related to sea horses, even for highly exploited species. This research was conducted to inventory sea horse resources (Hippocampus spp.), covering spesies information, size, sex ratio and density of seahorses from three potential locations, they are Bintan Island, Lampung and Tanakeke Island Waters. Field observation for seahorse resources was conducted at Bintan Island (Riau Islands Province) in March 2016, Lampung Bay (Lampung Province) in May 2016 and Tanakeke Islands (Takalar Regency, South Sulawesi) in June 2016 by purposive sampling method, interview with fisherman and collector and also literature study. A total of 5 seahorse species were found in three research locations, 4 species found in Bintan waters $(H$. comes, $H$. spinossisimus, H. hystrix and H. kuda), 2 species found in Lampung Bay (H. comes and H. kuda) and only 1 species found in Tanakeke (H.barbouri). Most of seahorse found during the study were categorized as sexually mature, dominated with seahorse $11-12 \mathrm{~cm}$ in size. The different types and densities of seahorses in
\end{abstract}


the three study sites are supported by differences in habitat where seahorses are occupied. The density of seahorses tended to be low due to over-exploitation, environmental change and habitat damage. Management measures based on biological aspects and ecological conditions of each region need to be carried out for sustainable seahorse fisheries.

Keywords: Seahorse, Hippocampus spp., Bintan Island, Lampung Bay, Tanakeke Island

\section{Pendahuluan}

Kuda laut telah lama dieksploitasi, baik dalam bentuk olahan kering sebagai obat tradisional, suvenir, tonik, maupun dalam keadaan hidup sebagai ikan hias, sehingga populasinya terancam. Cina adalah pasar langsung terbesar untuk kuda laut sebagai obat tradisional, sedangkan Eropa dan Amerika merupakan pasar terbesar kuda laut sebagai ikan hias. Selain karena eksploitasi untuk penangkapan, keberadaan kuda laut juga terancam oleh rusaknya terumbu karang, mangrove, padang lamun, dan habitat muara serta penangkapan secara tidak sengaja, khususnya oleh jaring pukat (trawl) yang digunakan untuk menangkap udang (Vincent 1996; Bruckner et al. 2005; William et al. 2014; Dermawan et al. 2015: Anonim 2016).

Informasi tentang sumberdaya kuda laut masih terbatas, dari 35 jenis spesies kuda laut di dunia yang terdaftar dalam IUCN redlist, 20 jenis terdaftar sebagai "data deficient" yang menggambarkan kurangnya informasi terkait kuda laut, bahkan untuk jenis yang sangat tereksploitasi (IUCN 2017). Tingginya ancaman terhadap kelestarian kuda laut di alam, menyebabkan biota ini dikategorikan Appendix II dalam perdagangan internasional, oleh Convention on International Trade in Endangered Species of Wild Flora and Fauna (CITES) sehingga penangkapan dan perdagangannya dibatasi berdasarkan kuota (Martin-Smith dan Vincent 2005).

Regulasi yang mengatur status perlindungan kuda laut secara nasional belum ditetapkan (Sadili 2015), tetapi beberapa batasan terkait penangkapan dan perdagangan kuda laut telah ada sebelumnya, yaitu : 1) pada tahun 2015, jenis kuda laut yang masuk dalam daftar ekspor adalah Hippocampus kuda dan H. comes dengan kuota sebanyak 5000 ekor; 2) kuota penangkapan dan penangkaran tahun 2015 hanya diberikan kepada provinsi Sulawesi Selatan; 3) kuda laut yang boleh diperdagangkan hanya yang berasal dari hasil pengembangbiakan dan dalam kondisi hidup; dan 4) kuda laut yang bisa ditangkap dan diperdagangkan minimum berukuran $10 \mathrm{~cm}$ (CITES 2005: KLHK 2015).

Data dan informasi tentang sumberdaya kuda laut sangat dibutuhkan dalam penetapan regulasi yang mengatur pemanfaatannya. Penelitian ini dilakukan untuk menginventarisir sumberdaya kuda laut (Hippocampus spp.) meliputi informasi jenis, nisbah kelamin dan ukuran dari tiga lokasi potensial, yaitu perairan Pulau Bintan (Provinsi Kepulauan Riau), Teluk Lampung (Provinsi Lampung) dan Pulau Tanakeke (Provinsi Sulawesi Selatan). Informasi tentang populasi kuda laut di alam merupakan data yang harus dikumpulkan untuk pengelolaan kuda laut yang adatif dan dapat dipertahankan (Bruckner et al. 2005).

\section{Metodologi}

Observasi sumberdaya kuda laut dilakukan di Pulau Bintan (Provinsi Kepulauan Riau) pada bulan Maret 2016, di Teluk Lampung (Provinsi Lampung) pada bulan Mei 2016 dan Kepulauan Tanakeke (Kabupaten Takalar, Sulawesi Selatan) pada bulan Juni 2016 dengan metode purposive sampling, wawancara dengan para nelayan serta pengepul kuda laut.

Pengambilan sampel kuda laut yang dilakukan secara purposive sampling dilakukan di area penangkapan kuda laut berdasarkan informasi yang didapatkan dari penduduk lokal. Kegiatan penangkapan oleh nelayan lokal di ketiga lokasi dilakukan dengan cara yang berbeda. Penangkapan kuda laut di Bintan dan Lampung dilakukan oleh nelayan tanpa menggunakan alat tangkap tertentu, dengan cara snorkeling, yaitu mereka berenang untuk mengambil kuda laut. Dengan mempertimbangkan keberadaan kuda laut yang sangat jarang, pengamatan populasi kuda laut di Teluk Lampung dilakukan dengan surface visual census (SVC) mengikuti lokasi snorkeling nelayan yang akan menangkap kuda laut. Metode ini dibantu dengan GPS yang mencatat titik koordinat (tracking) selama pengambilan sampel kuda laut berlangsung, sehingga dapat diestimasi luasan area sampling. Adapun di perairan Bintan, estimasi area sampling tidak dilakukan karena padatnya vegetasi laut (Gambar 1) serta arus yang cukup kencang sehingga tracking lokasi tidak bisa dilakukan. Data kuda laut di perairan Bintan didapatkan dari hasil tangkapan nelayan yang telah dibawa ke darat.

Berbeda dengan kedua lokasi sebelumnya, kegiatan penangkapan kuda laut di 
Perairan Tanakeke dilakukan dengan menggunakan alat seser yang didorong di ekosistem lamun. Pengamatan populasi kuda laut di perairan Tanakeke dibantu dengan menggunakan seser (lebar mulut $2 \mathrm{~m}$ ) yang didorong sepanjang $\pm 200 \mathrm{~m}$ dan dilakukan di lima lokasi, kecuali stasiun 4 yang dilakukan dengan metode surface visual census. Lokasi penelitian serta titik koordinat kuda laut di ketiga lokasi ditampilkan pada Gambar 2-4 dan Tabel 1.

Kuda laut diidentifikasi berdasarkan Lourie et al. (2001, 2004), diamati jenis kelaminnya kemudian diukur tingginya yaitu jarak antara ujung coronet (mahkota) sampai ujung ekor yang diluruskan. Karakter yang digunakan untuk mengidentifikasi kuda laut diantaranya panjang moncong, tinggi spesimen, jumlah duri di pipi dan mata, tinggi dan bentuk koronet serta pola atau tanda seperti garis atau spot (Gambar 5a). Nisbah kelamin kuda laut diketahui berdasarkan perbandingan jumlah kuda laut betina dan jantan yang tertangkap selama penelitian (Effendi 1997) dan dianalisis dengan uji ChiSquare $\left(\chi^{2}\right)$ dengan hipotesis sebagai berikut :

$\mathrm{H}_{0}$ Tidak ada perbedaan yang nyata antara jumlah kuda laut jantan dan betina yang muncul (nisbah kelamin antara jantan dan betina adalah seimbang, yakni $1: 1$ )

H1 Terdapat perbedaan yang nyata antara : jumlah kuda laut jantan dan betina yang muncul $(1 \neq 1)$.

Kuda laut jantan dan betina dibedakan dengan melihat keberadaan kantung anak yang hanya terdapat pada kuda laut jantan (Gambar 5bc). Pengamatan nisbah kelamin kuda laut sebagai salah satu aspek dalam biologi reproduksi diperlukan dalam menilai potensi reproduksinya (Vicentini dan Araujo 2003).

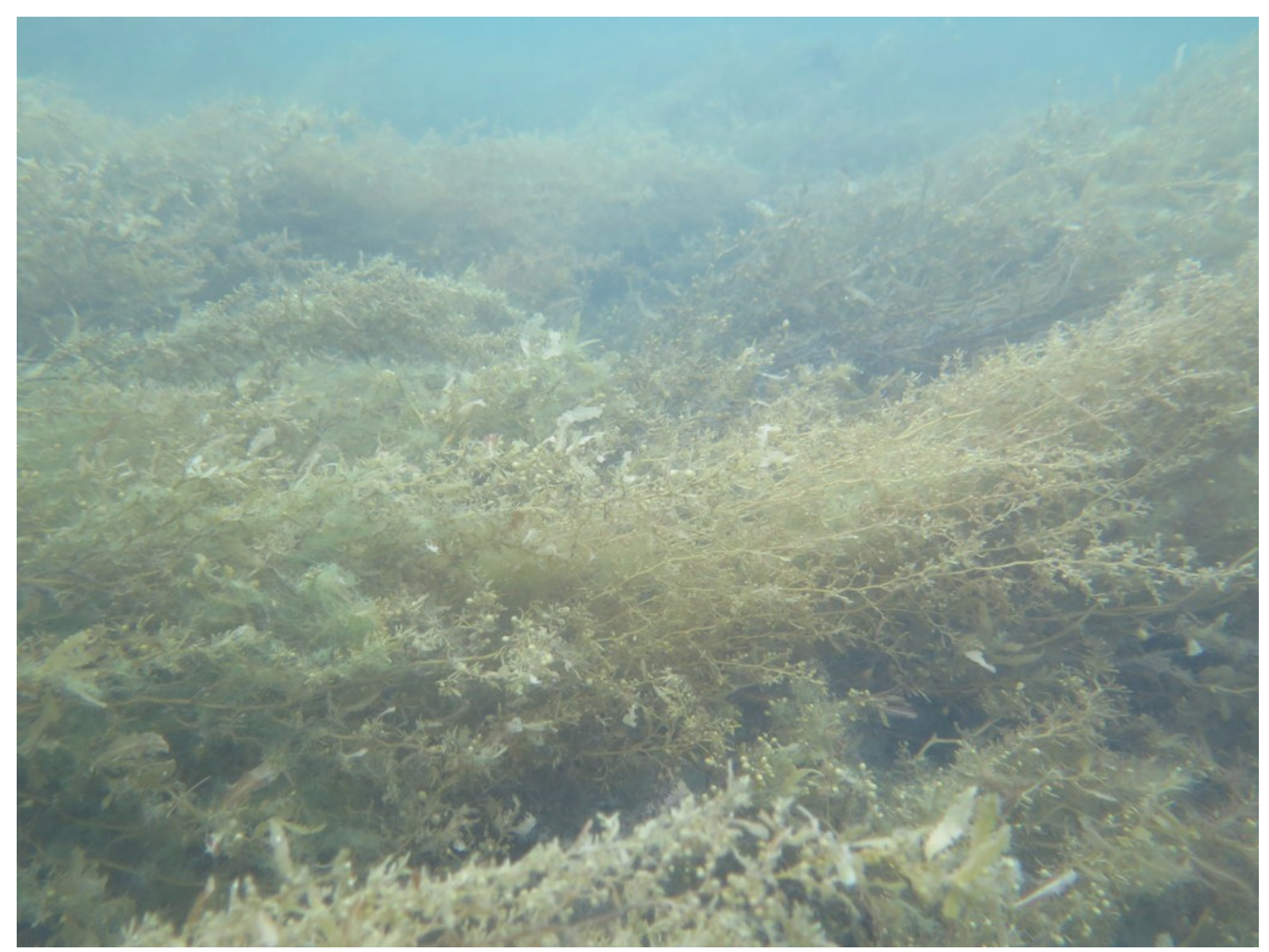

Gambar 1. Habitat kuda laut di pesisir utara Bintan (BP2KSI 2016).

Figure 1. Habitat of seahorse in north coast of Bintan (BP2KSI 2016). 


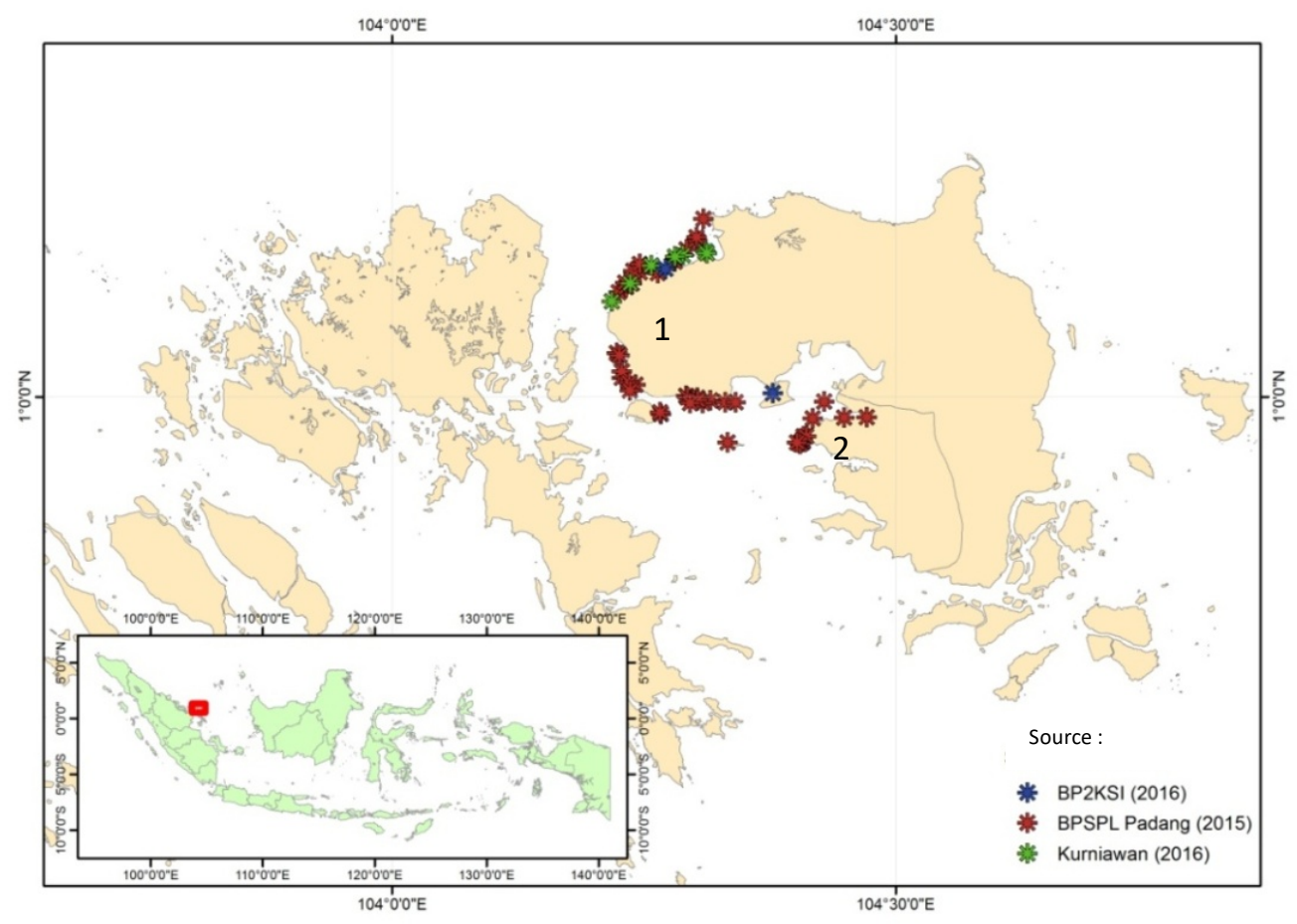

Gambar 2. Peta Lokasi penelitian di Pulau Bintan.

Figure 2. Research location map in Bintan Island.

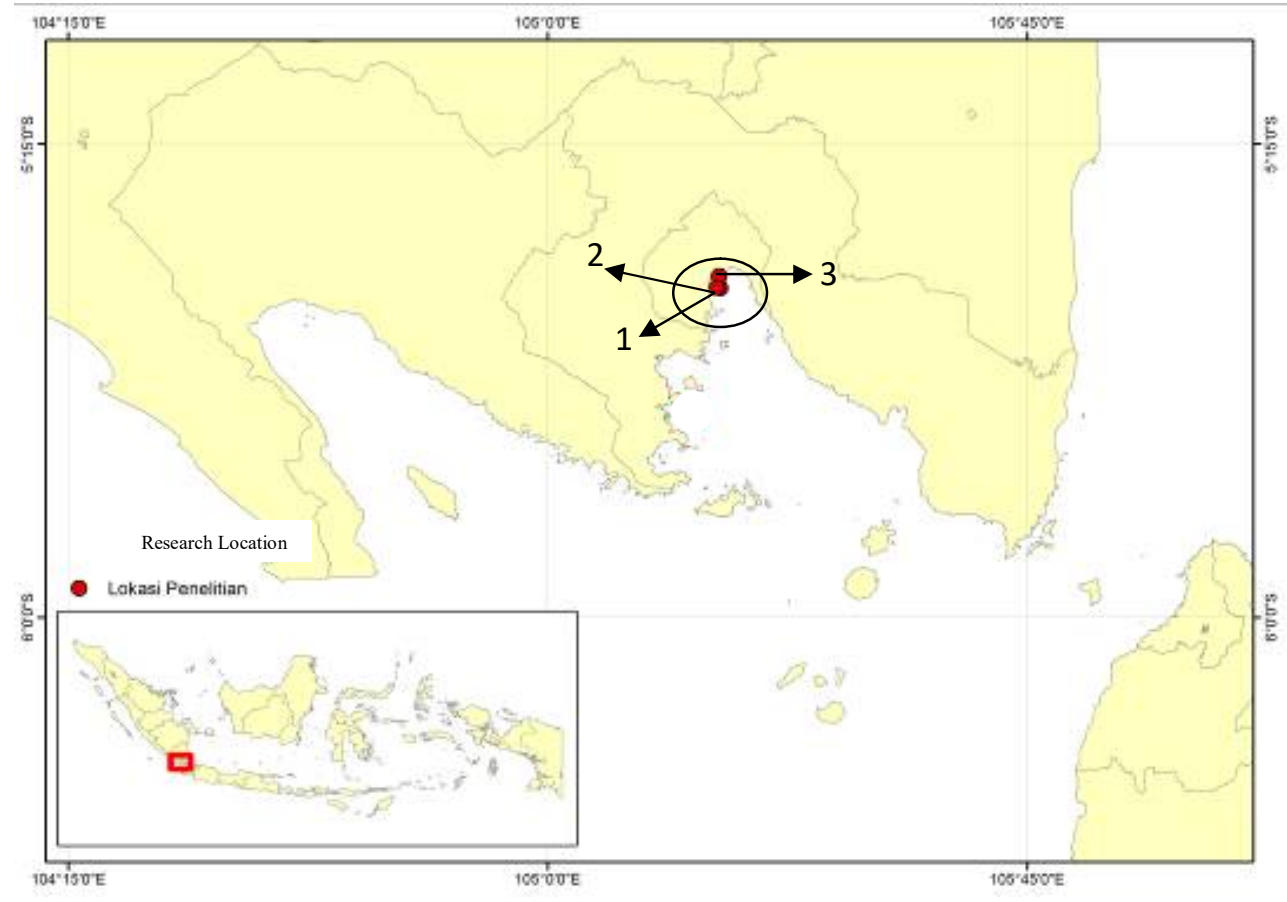

Gambar 3. Peta lokasi penelitian di Teluk Lampung.

Figure 3. Research location map in Lampung Bay. 


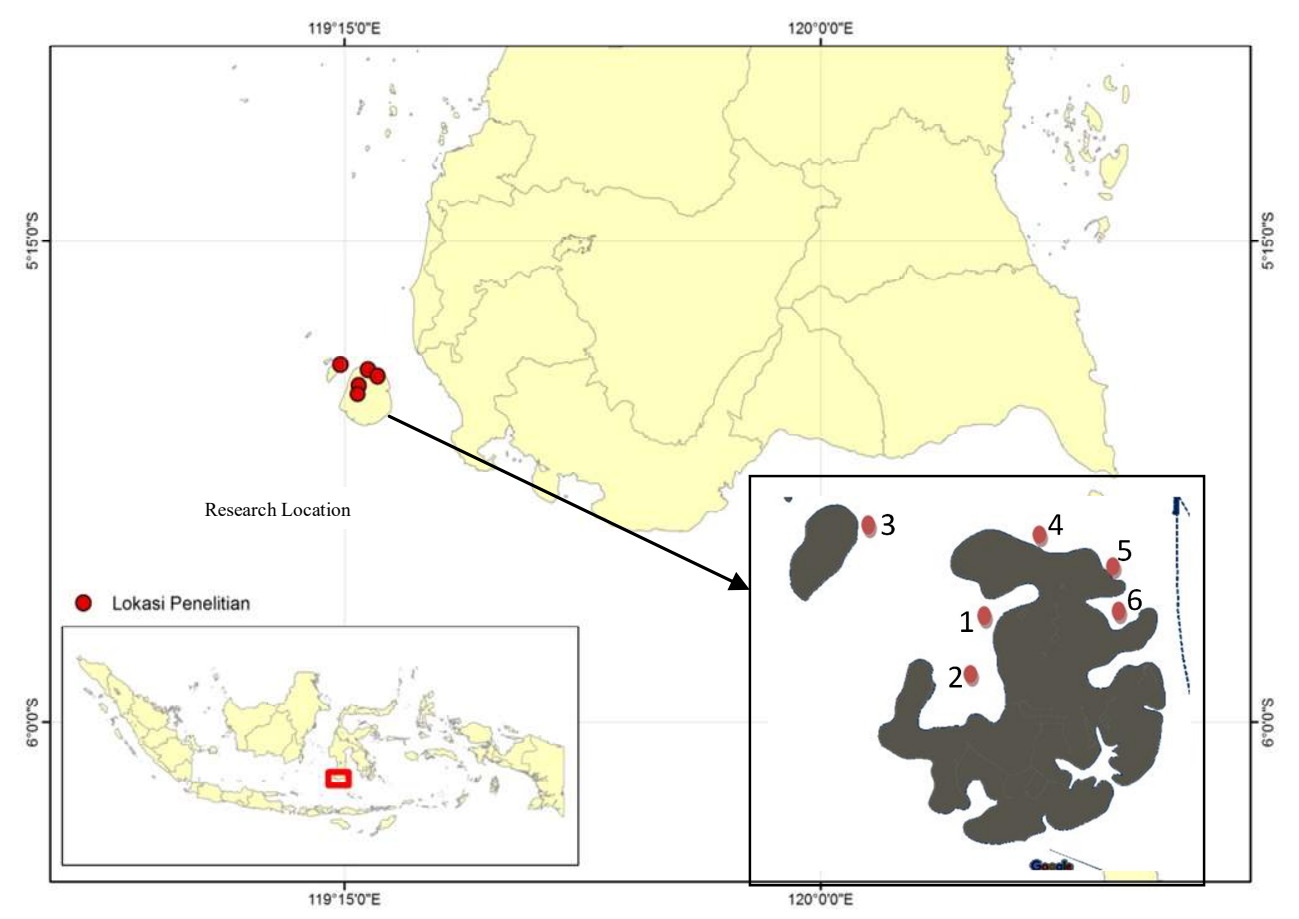

Gambar 4. Peta lokasi penelitian di perairan Kepulauan Tanakeke.

Figure 4. Research location map in Tanekeke Islands.

Tabel 1. Titik koordinat lokasi penelitian.

Table 1. Coordinate points of research location.

\begin{tabular}{cllcc}
\hline Station code & \multicolumn{1}{c}{ Province } & \multicolumn{1}{c}{ Location } & Latitude & Longitude \\
\hline 1 & Riau Islands & Sakera & 1.128 & 104.271 \\
2 & Riau Islands & Pengujan & 1.004 & 104.378 \\
\hline 1 & Lampung & Gosong Pasir Lebar & -5.479 & 105.270 \\
2 & Lampung & Gosong Kapal Keruk & -5.460 & 105.268 \\
3 & Lampung & Gosong Pasir Kecil & -5.478 & 105.264 \\
\hline 1 & South Sulawesi & La'botalua & -5.475 & 119.273 \\
2 & South Sulawesi & Taka taka'labua & -5.489 & 119.271 \\
3 & South Sulawesi & Pulau Bouluang & -5.444 & 119.244 \\
4 & South Sulawesi & Bag. Utara Tanakeke & -5.451 & 119.287 \\
5 & South Sulawesi & La'bolambere & -5.460 & 119.303 \\
6 & South Sulawesi & Butungpai & -5.470 & 119.307 \\
\hline
\end{tabular}




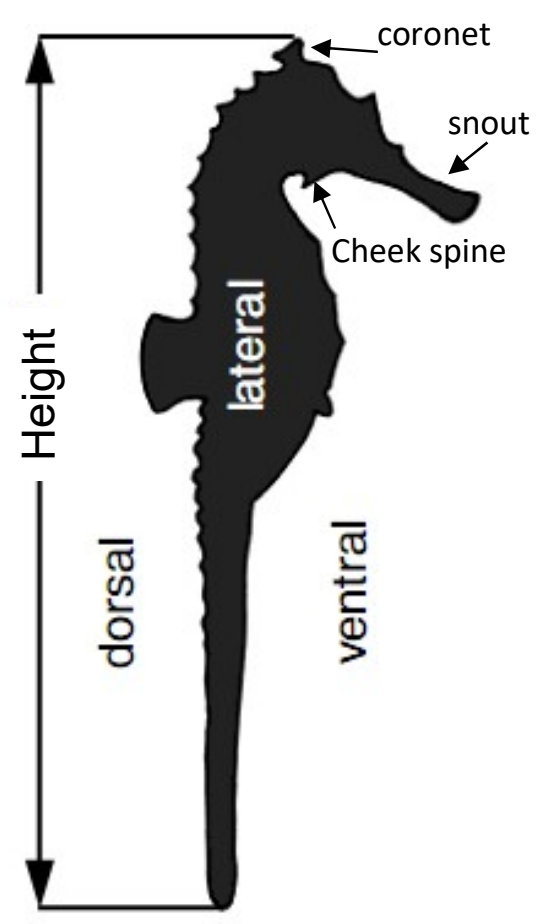

a

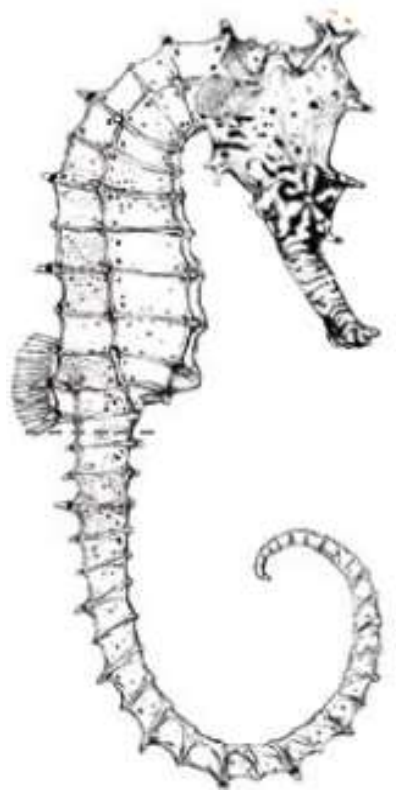

b

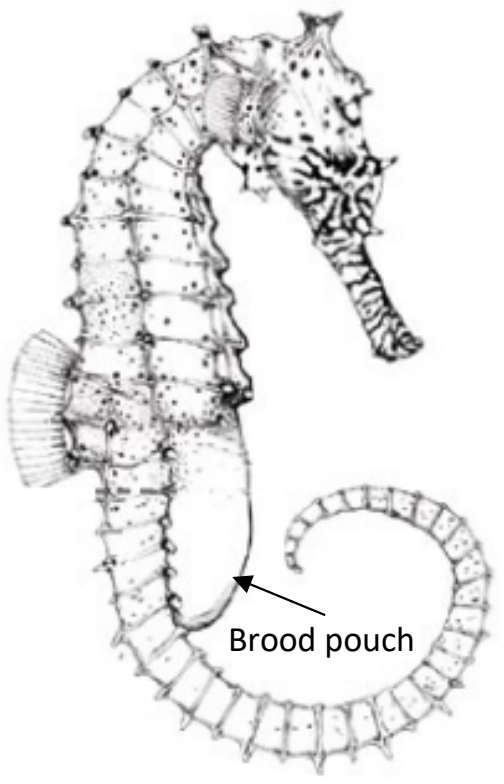

C

Gambar 5. a. Pengukuran tinggi kuda laut, b. kuda laut betina, dan c. kuda laut jantan.

Figure 5. a. Height measuring of seahorse, b. female seahorse, and c. male seahorse.

Kepadatan kuda laut didapatkan dengan menggunakan rumus (Dermawan et al. 2015):

keterangan :

$\mathrm{K}=$ Kepadatan jenis $\left(\mathrm{ekor} / \mathrm{m}^{2}\right)$

$\mathrm{X}=$ Jumlah individu hasil tangkapan (ekor)

$\mathrm{A}=$ Luas area yang disisir $\left(\mathrm{m}^{2}\right)$

\section{Hasil}

Sumberdaya kuda laut yang ditemukan di ketiga lokasi penelitian menunjukkan perbedaan jenis maupun jumlah. Hasil penelitian di Perairan Sakera yang terletak di pesisir utara Pulau Bintan ditemukan dua jenis kuda laut yaitu Hippocampus comes (28 ekor) dan H. hystrix (1 ekor). Ukuran H.comes yang tertangkap berkisar antara 8,3-14,2 cm dan untuk $H$. hystrix adalah $14,5 \mathrm{~cm}$. H. comes teridentifikasi dengan ciri-ciri berupa koronet rendah, dua duri di pipi dan ekor yang bergaris (Gambar 6). Berbeda dengan tangkapan kuda laut di pantai utara, di bagian selatan Pulau Bintan (Perairan Penghujan) teridentifikasi dua jenis kuda laut dalam bentuk kering dari pengumpul kuda laut yaitu H. spinossisimus dan H. kuda. Kuda laut yang tersedia di pengepul dalam bentuk kering, sehingga pengamatan aspek biologinya tidak dilakukan. Jenis kuda laut yang ditemukan di perairan selatan Bintan ditampilkan pada Gambar 7.

$$
\mathrm{K}=\mathrm{X} / \mathrm{A}
$$

Bintan berjenis kelamin jantan sedangkan $H$ comes yang tertangkap sebanyak 12 ekor jantan dan 16 ekor betina. Kuda laut (H. comes) betina yang tertangkap di perairan Bintan berkisar antara 8,3-13,5 cm dan kuda laut jantan yang tertangkap memiliki tinggi antara 9,2-14,5 cm, dengan dominasi ukuran berkisar 11-12 cm. Nisbah kelamin $H$. comes saat penelitian adalah 1:0,75 dengan nilai chi-square $(\chi 2) \quad 0,571$, yang menunjukkan tidak ada perbedaan yang nyata antara jumlah kuda laut jantan dan betina. Gambar 6 menunjukkan sebaran ukuran kuda laut yang tertangkap di pesisir utara Bintan.

Jenis kuda laut yang ditemukan di Teluk Lampung adalah jenis $H$. comes dan $H$. kuda (4 ekor jenis $H$. comes dan 1 ekor jenis $H$. kuda) yang ditampilkan pada Gambar 9. Ukuran kuda laut yang didapatkan berkisar antara $8-13,5 \mathrm{~cm}$ dengan berat antara 2,5-15,72 gram. Kelima ekor kuda laut yang ditemukan di perairan Teluk Lampung berjenis kelamin betina. Kepadatan 
kuda laut tanpa membedakan jenisnya di Teluk Lampung sebesar $0,00125 \mathrm{ekor} / \mathrm{m}^{2}$ (atau 1,25 ind/ha) dan hanya ditemukan di Gosong Pasir di Teluk Lampung.

Berbeda dengan kuda laut yang tertangkap di perairan Bintan dan Lampung, jenis kuda laut yang tertangkap di perairan Pulau Tanakeke adalah $H$. barbouri sebanyak 16 ekor betina dan 23 ekor jantan (Gambar 10). Ukuran kuda laut betina yang tertangkap di perairan Tanakeke berkisar antara 7,6-13,3 cm dan kuda laut jantan yang tertangkap memiliki tinggi antara $11-14 \mathrm{~cm}$. Kuda laut yang tertangkap di Tanakeke didominasi ukuran 11-12 cm (Gambar 11). Nisbah kelamin kuda laut $H$. barbouri sebesar 1:1,44, dengan nilai chi-square $(\chi 2)$ 1,256 menunjukkan tidak adanya perbedaan yang nyata antara jumlah kuda laut jantan dan betina di perairan Tanakeke. Enam ekor kuda laut jantan tertangkap dalam kondisi hamil besar dan beberapa diantaranya mengeluarkan anaknya dalam wadah penampungan. Kuda laut dapat ditemukan di lima stasiun penelitian yang ada di perairan Tanakeke dengan jumlah yang bervariasi. Kepadatannya berkisar antara $0,005-0,02$ ekor $/ \mathrm{m}^{2} \quad(50-200$ ekor/ha).

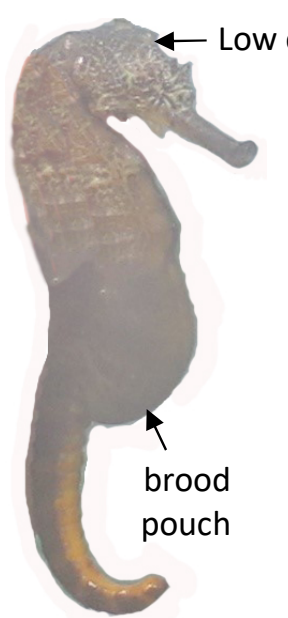

(a)

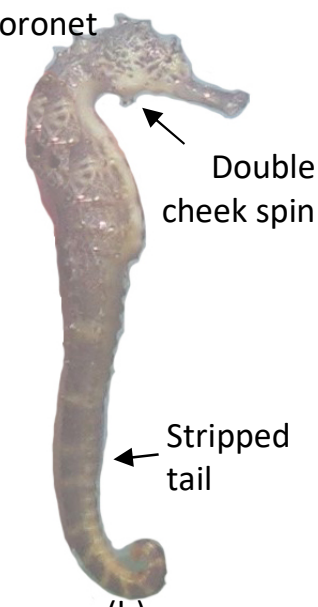

(b)

Gambar 6. (a) Kuda laut (H. comes) jantan, dan (b) betina di pantai utara Bintan.

Figure 6. (a) Male and (b) female of Hippocampus comes from north coast of Bintan.

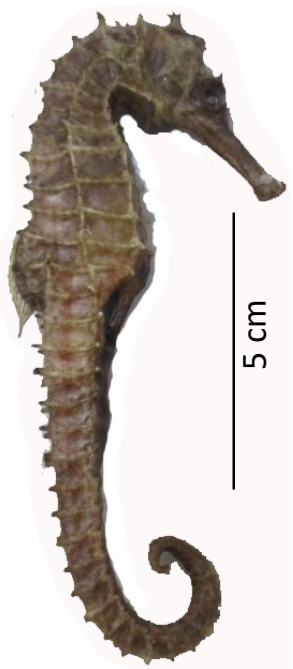

H. spinnossisimus

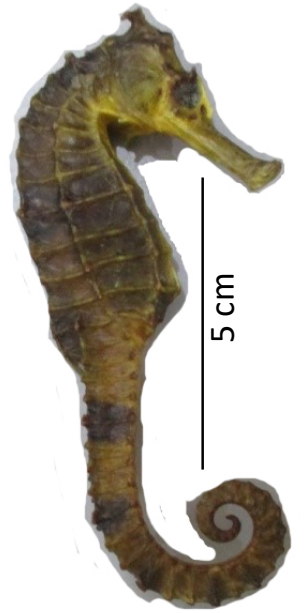

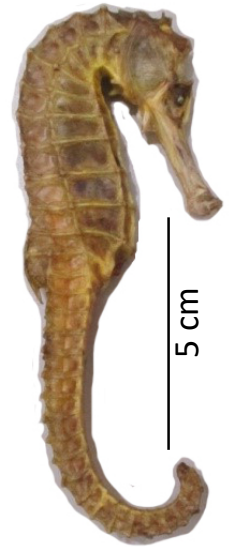

H. kuda

Gambar 7. Dokumentasi jenis kuda laut kering yang ditemukan di pesisir selatan Bintan.

Figure 7. Dried seahorse species documentation from south coast of Bintan. 
Putri et al.

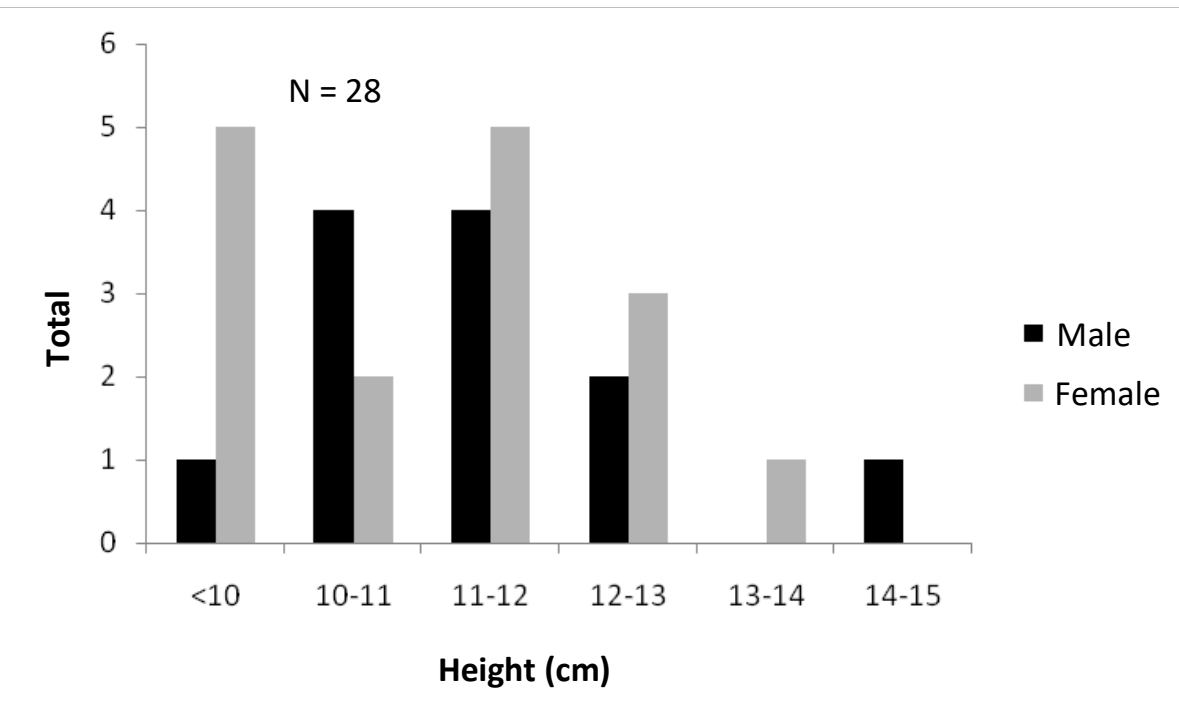

Gambar 8. Sebaran ukuran kuda laut di pesisir utara Bintan.

Figure 8. Size distribution of seahorse from north coast of Bintan.

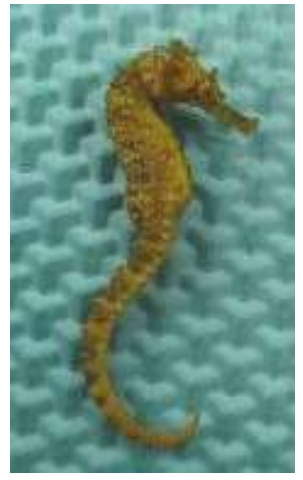

H. comes

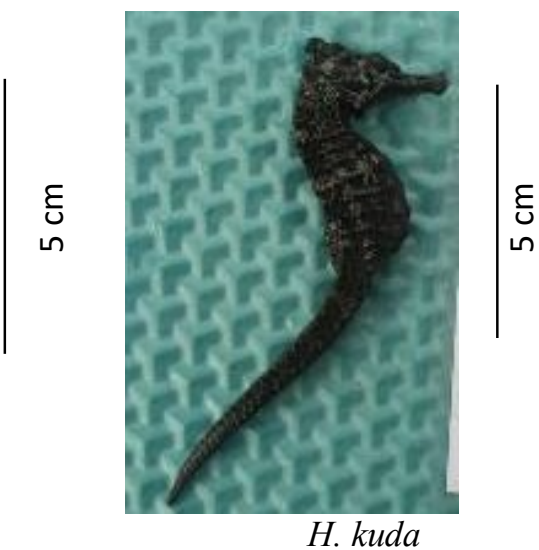

Gambar 9. Dua jenis kuda laut yang ditemukan di perairan Lampung.

Figure 9. Two species of seahorses from Lampung Bay.

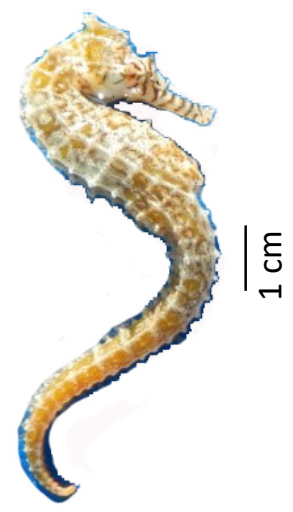

Gambar 10. H. barbouri yang ditemukan di perairan Tanakeke.

Figure 10. H. barbouri from Tanakeke waters. 


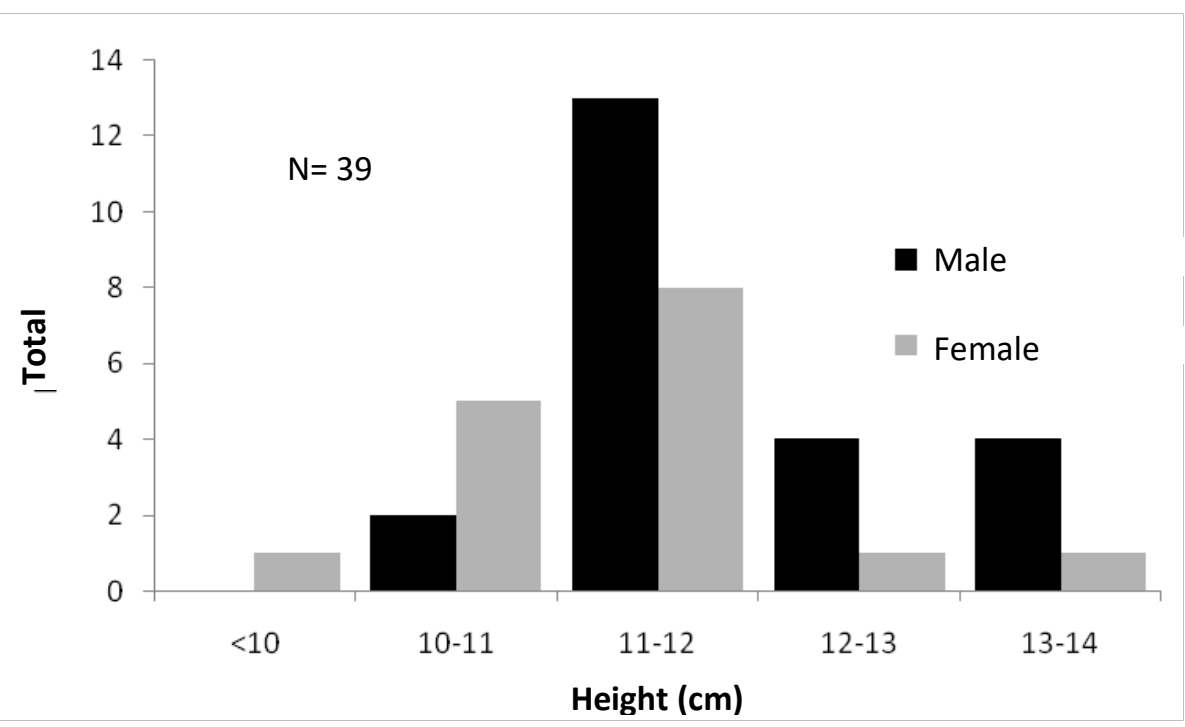

Gambar 11. Sebaran ukuran kuda laut di perairan Tanakeke, Kabupaten Tarakan, Sulawesi Selatan. Figure 11. Size distribution of seahorse from Tanakeke Island, Tarakan Regency, South Sulawesi.

\section{Pembahasan}

Pada penelitian ini ditemukan empat jenis kuda laut di perairan Bintan yaitu $H$. hystrix, $H$. spinnossisimus, $H$. comes, dan $H$. kuda. Berdasarkan hasil monitoring BPSPL (2005) setidaknya ada tujuh jenis kuda laut yang dilaporkan hidup di kawasan ini yaitu $H$. comes, H. hystrix, H. kuda, H. spinosissimus, $H$. barbouri, H. kelloggi, dan $H$. reidi. Menurut Fianda et al. (2016), musim kemunculan kuda laut di Perairan Pulau Bintan biasanya terjadi pada bulan Februari hingga bulan Mei dan bulan Oktober, dengan puncaknya pada bulan Maret dan April yang ditandai dengan musim kemunculan rengkam (sejenis alga coklat, Sargassum sp.). Menurut Kurniawan (2016), kepadatan kuda laut di perairan utara Bintan berkisar antara 11,29$26,95 \mathrm{ind} / \mathrm{ha}\left(0,001-0,002 \mathrm{ind} / \mathrm{m}^{2}\right)$. Kepadatan kuda laut yang tertangkap di perairan ini dipengaruhi oleh aksesibilitas lokasi penangkapan, seperti contohnya lokasi yang sulit dijangkau seperti Pantai Tuli, kepadatan kuda lautnya masih tinggi. Jika dibandingkan dengan kepadatan kuda laut $(H$. reidi) yang ditemukan di pesisir Brazil (0,01-0,09 ind $\left./ \mathrm{m}^{2}\right)$, kepadatan kuda laut yang ditemukan di perairan Bintan tergolong rendah (Freret-Meurer et al. 2018).

Meskipun penangkapan kuda laut di Teluk Lampung sudah dilakukan sejak lama, data dan informasi terkait populasi kuda laut yang tertangkap di Teluk Lampung sulit ditemukan. Berdasarkan hasil wawancara, kuda laut di Teluk Lampung jarang ditemukan dalam beberapa tahun terakhir. Selain jumlah tangkapan kuda laut saat ini lebih sedikit, lokasi penangkapannya juga menjauh dari garis pantai (Abdul Latif, nelayan lokal, komunikasi pribadi). Dengan demikian, tidak ada data penelitian terdahulu secara kuantitatif yang dapat digunakan sebagai acuan pembanding dengan kondisi populasi dan hasil tangkapan nelayan kuda laut di Teluk Lampung pada saat ini. Kuda laut yang tertangkap di Teluk Lampung dimanfatkan untuk kegiatan budidaya, dengan jenis yang menjadi indukan biasanya adalah H. kuda (Sukmono 2004).

Jenis $H$. barbouri merupakan jenis kuda laut yang sering ditemukan di perairan Tanakeke sebagaimana juga hasil penelitian sebelumnya oleh Syafiuddin (2010), Santoso (2014) dan Mulyawan dan Saokani (2015). Kepadatan populasi kuda laut di perairan Tanakeke bervariasi dan tampaknya bergantung kepada keberadaan lamun dan vegetasi laut lainnya serta arus laut sebagaimana yang disampaikan Teixeira dan Musick (2001). Variasi kepadatan kuda laut di perairan Tanakeke terlihat dari hasil penelitian Mulyawan dan Saokani (2015) sebesar 0,0006$0,0033 \mathrm{ind} / \mathrm{m}^{2}$ dan Syafiuddin et al. (2004) sebesar $0,15-1,26 \mathrm{ind} / \mathrm{m}^{2}$.

Kepadatan kuda laut di ketiga lokasi cenderung rendah seperti yang ditemukan di beberapa perairan lainnya. Di beberapa pantai di bagian selatan Brazil, kepadatan kuda laut berkisar antara 0,01-0,09 ind/m2 (Freret-Meurer et al. 2018), di Filipina 0,02 ind $/ \mathrm{m} 2$ (Apale dan Foster 2016), dan di pantai Aracatiba, Brazil, kepadatan rata-rata kuda laut sebesar $0,18 \mathrm{ind} / \mathrm{m}^{2}$ (Freret-Meurer dan Andreata 2008). Rendahnya populasi kuda laut di berbagai belahan dunia termasuk Indonesia, sebagaimana yang disampaikan Lourie et al. (2001) dan Foster dan 
Putri et al.

Vincent (2004), diakibatkan dari eksploitasi yang berlebihan seperti yang terjadi di perairan Bintan saat musim kemunculan kuda laut. Perubahan lingkungan akibat dari peningkatan aktivitas manusia di pesisir sebagaimana yang terjadi di Teluk Lampung (Wijayanti 2007) dan kerusakan habitat misalnya akibat pencemaran limbah minyak di perairan Bintan (Panama 2016) diduga dapat mempengaruhi keberlanjutan populasi kuda laut. Menurut Apale dan Foster (2016), rendahnya kepadatan populasi kuda laut akan menimbulkan masalah bagi kuda laut dalam menemukan pasangan.

Lourie et al. (1999) dan Vincent dan Sadler (1995) menyatakan bahwa kuda laut yang kehilangan pasangannya tidak dapat bereproduksi kembali sampai menemukan kembali pasangan baru. Mobilitas yang lambat, kepadatan yang rendah dan hanya bergantung pada penyamaran (kamuflase) sebagai bentuk pertahanan menyebabkan pencarian pasangan baru akan membutuhkan waktu dan energi yang besar. Meski demikian, berdasarkan hasil penelitian Syafiuddin (2010) diketahui kuda laut $H$. barbouri yang didapatkan dari perairan Tanakeke tidak bersifat monogami, karena kuda laut jantan ataupun betina dapat menerima pasangan baru setelah pemijahan berikutnya dalam wadah budidaya. Begitupun menurut Sukmono (2004), kuda laut betina mampu kawin dengan lebih dari satu jantan pada satu kali siklus perkawinan dan tipe perkawinan pada kuda laut adalah poliandri. Hasil ini tentunya dapat bermanfaat dalam pengelolaan kuda laut yang berkelanjutan. Usaha budidaya kuda laut yang rentan terhadap penyakit dan umumnya masih bergantung pada induk alam tentunya berdampak negatif pada kelangsungan hidup kuda laut. Keberhasilan pemijahan dan pergantian pasangan kuda laut dapat digunakan dalam pengembangan pembenihan dan peningkatan produksi benih kuda laut.

Walau jumlah kuda laut dari ketiga lokasi penelitian menunjukkan perbedaan, tetapi parameter lingkungan perairan yang didapatkan dari ketiga lokasi penelitian relatif sama (Tabel 2). Menurut Teixeira dan Musick (2001), parameter abiotik seperti fisika dan kimia air tidak mempunyai korelasi terhadap kelimpahan kuda laut (Hippocampus erectus). Bahkan tren perubahan kondisi lingkungan tidak dapat menjelaskan variasi kepadatan kuda laut di tiga pantai di perairan selatan Brazil yaitu Pantai João Fernandes, Pantai Canto dan Pantai Ossos (Freret-Meurer et al. 2018).

Jenis dan kepadatan kuda laut yang berbeda di ketiga lokasi penelitian didukung oleh perbedaan habitat dimana kuda laut ditemukan.
Jenis Hippocampus comes yang banyak ditemukan di perairan Bintan berasosiasi dengan hamparan alga coklat dan lamun yang tersebar di lokasi penelitian. H. barbouri, jenis kuda laut yang ditemukan di perairan Tanakeke selain banyak ditemukan di ekosistem lamun, Enhalus acoroides, juga ditemukan di perairan terbuka dengan sedimen berbutiran halus (pasir dan lumpur). Kuda laut (H. kuda dan H. comes) yang ditemukan di perairan Teluk Lampung dengan jumlah yang lebih sedikit ditemukan di perairan terbuka dengan substrat berpasir dan vegetasi air (alga dan lamun) yang tersebar (BP2KSI 2016). Menurut Foster dan Vincent (2004), H. comes dapat hidup di berbagai habitat seperti alga/makroalga, karang, lamun dan spon, $H$. barbouri habitatnya hanya di lamun dan karang, sedangkan $H$. kuda memiliki distribusi yang lebih luas mencakup alga/makroalga, mangrove, bebatuan, lamun dan substrat berpasir. Hamparan alga coklat serta padang lamun yang ditemukan di pesisir Pulau Bintan dan Tanakeke menjadi lokasi yang aman bagi kuda laut untuk melengkapi siklus hidupnya sehingga bisa memijah, terhindar dari predator serta mensuplai makanan yang berlimpah. Buzá-Jacobucci dan Pereira-Leite (2014) menyatakan bahwa Sargassum dan organisme yang menempel padanya berperan penting dalam menyediakan sumber makanan bagi amphipoda, yang nantinya menjadi makanan bagi kuda laut. Sargassum sp. sebagai mikrohabitat yang paling banyak digunakan oleh kuda laut untuk mencari makan, perlindungan serta reproduksi juga ditemukan di perairan selatan Brazil, selain sponge Aplysina fulva (Freret-Meurer et al. 2018).

Jika mengacu pada aturan perdagangan internasional (CITES 2005), sebagian besar kuda laut yang ditemukan selama penelitian telah matang secara seksual dengan ukuran dominan yaitu 11-12 cm. Menurut Foster dan Vincent (2005), kuda laut dapat dikategorikan matang secara seksual ketika tingginya mencapai $10 \mathrm{~cm}$ dan ukuran ini menjadi ukuran minimum yang boleh ditangkap dari alam serta diperdagangkan secara internasional.

Sebagian besar kuda laut yang tertangkap di perairan utara Bintan pada musim tangkap (bulan Februari-April) berada dalam kondisi matang gonad (Kurniawan 2016). Bahkan berdasarkan hasil wawancara yang dilakukan oleh BPSPL Padang (2015), 80\% dari hasil tangkapan nelayan dalam kondisi hamil. Penyeleksian hasil tangkapan kuda laut jantan yang hamil dan mengandangkannya (caging) sampai mereka melahirkan merupakan salah satu rekomendasi yang dapat diaplikasikan dalam pemulihan 
populasi kuda laut (Bruckner et al. 2005). Tentunya langkah ini hendaknya diikuti dengan observasi terkait kualitas lingkungan dan habitat yang tepat serta evaluasi pertahanan hidup juvenil kuda laut.

Keberadaan kuda laut jantan yang tidak ditemukan selama penelitian di Teluk Lampung dapat memengaruhi keberlanjutan populasi kuda laut. Kuda laut betina yang siap memijah harus melepaskan telurnya di kantong pengeraman kuda laut jantan. Jika tidak ada kuda laut jantan, maka telur-telur akan terlepas ke air. Menurut Schultz dan Stren dalam Sukmono (2004), reproduksi kuda laut di alam terjadi sepanjang tahun, tetapi induk kuda laut betina memiliki siklus reproduksi yang lebih pendek dibandingkan dengan induk jantan. Kuda laut jantan hanya dapat menerima telur-telur betina setiap pengeraman, tanpa dapat mempercepat masa pengeraman.

Hasil analisis statistik menunjukkan tidak adanya perbedaan yang nyata antara jumlah kuda laut jantan dan betina yang ditemukan di perairan Bintan dan Tanakeke. Nisbah kelamin kuda laut biasanya 1:1 (Vicentini dan Araujo 2003) karena hewan ini merupakan hewan monogami (Lourie et al. 1999). Penghitungan nisbah kelamin dengan statistik di Perairan Teluk Lampung tidak dilakukan karena tidak ditemukannya kuda laut jantan. Nilai nisbah kelamin yang didapatkan dari ketiga lokasi penelitian belum menggambarkan nisbah kelamin secara periodik karena hanya diukur pada bulan-bulan tertentu saja. Meski demikian, diharapkan informasi ini dapat menjadi informasi awal untuk kegiatan penelitian selanjutnya. Berdasarkan beberapa referensi, nisbah kelamin populasi kuda laut di berbagai perairan tidak sama. Kondisi ini merupakan hal biasa sebagai karakteristik khas dan spesifik dari masing-masing lokasi serta menjadi indikasi bahwa setiap area memberikan peran penting dalam mempertahankan populasi kuda laut di area tersebut (Freret-Meurer et al. 2018).

Meskipun masih dapat ditemukan, populasi kuda laut terus menurun di lokasi-lokasi potensial seperti halnya Bintan, Lampung dan Tanakeke. Contohnya dahulu di Tanakeke, dalam satu hari nelayan bisa mendapatkan 100-200 ekor kuda laut per orang sedangkan saat ini dalam satu hari kuda laut yang tertangkap kurang dari 20 ekor (Dg. Mu'ding, nelayan lokal, komunikasi pribadi). Kondisi ini tidak hanya terjadi di Indonesia, tetapi juga di negara-negara lain yang memiliki perikanan kuda laut yang telah mengalami penurunan jumlah (recruitment overfishing) dan penurunan ukuran (growth overfishing) kuda laut dari berbagai spesies (Bruckner et al. 2005).

Pembatasan kuota tangkapan dan ekspor yang selama ini diterapkan di Indonesia bukan hanya satu-satunya jalan dalam pengelolaan kuda laut (KLHK 2015). Sebagai komoditas unggulan, kuda laut tetap menjadi primadona dalam perdagangan internasional sehingga keberlanjutannya perlu tetap diperhatikan. Sebagaimana di Filipina, penelitian populasi kuda laut di Indonesia masih dibutuhkan dalam jangka panjang dan time series yang mencakup distribusi geografik, kelimpahan relatif, ukuran rata-rata, jumlah jantan yang hamil dan nisbah kelamin untuk mengetahui kesehatan populasi kuda laut, dampak merugikan dari rekanan penangkapan serta efektivitas pengelolaan kuda laut (Apale dan Foster 2016). Informasi yang didapatkan tentang aspek biologi dan kondisi ekologi, dapat dijadikan bahan dalam langkah pengelolaannya seperti pembatasan ukuran penangkapan, penutupan secara spasial atau temporal, perputaran masa atau waktu panen dan penangkapan dengan menseleksi kuda laut jantan yang hamil. Pemanfaatan kuda laut yang berkelanjutan juga dapat didukung dengan menyediakan dan memonitoring data populasi dan perdagangan, meningkatkan koordinasi dan partisipasi antarpemangku kepentingan, dan mengkaji kemampuan produksi kegiatan budidaya dengan melihat derajat ketergantungan terhadap populasi alam serta dampaknya terhadap lingkungan (Bruckner et al. 2005).

Tabel 2. Parameter perairan di lokasi ditemukannya kuda laut.

Table 2. Water parameter in locations where seahorses been found.

\begin{tabular}{lcccc}
\hline Environment parameters & Unit & Bintan & Lampung & Tanakeke \\
\hline Water clarity & $\mathrm{m}$ & $0,9-2,3$ & $1,2-1,6$ & $0,3-2$ \\
Temperature & ${ }^{\circ} \mathrm{C}$ & $27,4-32,6$ & $30,8-31,8$ & $31-33,9$ \\
Turbidity & $\mathrm{NTU}$ & - & $1,29-7,04$ & $0,24-3,17$ \\
Salinity & $\%$ o & $28,8-33,5$ & $29-30$ & $32-35$ \\
\hline Data source & & Kurniawan (2016) & BP2KSI (2016) & BP2KSI (2016) \\
\hline
\end{tabular}


Tabel 3. Nisbah kelamin kuda laut di beberapa perairan.

Table 3. The sex ratio of seahorse from some waters.

\begin{tabular}{clcl}
\hline No. & \multicolumn{1}{c}{ Locations } & Sex ratio & \multicolumn{1}{c}{ References } \\
\hline 1 & The coast of Bintan, Riau Islands & $1: 0,75$ & Primary data \\
2 & Tanakeke Island, Takalar Regency & $1: 1,44$ & Primary data \\
3 & Canto Beach, Brazil & $2: 1$ & Freret-Meurer et al. $(2018)$ \\
4 & João Fernandes Beach, Brazil & $1: 1$ & Freret-Meurer et al. $(2018)$ \\
5 & Osso Beach, Brazil & $1: 2$ & Freret-Meurer et al. $(2018)$ \\
6 & Chesapeake Bay, Virginia & $0,6: 1$ & Teixeira and Musick (2001) \\
\hline
\end{tabular}

\section{Kesimpulan}

Jenis dan kepadatan kuda laut yang berbeda di ketiga lokasi penelitian didukung oleh perbedaan habitat. Kepadatan kuda laut di ketiga lokasi penelitian cenderung rendah akibat eksploitasi yang berlebihan, perubahan lingkungan dan kerusakan habitat. Hasil analisis statistik menunjukkan tidak adanya perbedaan yang nyata antara jumlah kuda laut jantan dan betina yang ditemukan di perairan Bintan dan Tanakeke. Langkah pengelolaan berbasis aspek biologi dan kondisi ekologi dari masing-masing wilayah perlu dilakukan untuk perikanan kuda laut yang berkelanjutan.

\section{Persantunan}

Makalah ini merupakan bagian dari penelitian "Ecological and biological assessment biota laut dilindungi terbatas: kima (Tridacna spp.), bambu laut (Isis spp.) dan kuda laut (Hippocampus spp.) " tahun 2016 di Balai Penelitian Pemulihan dan Konservasi Sumberdaya Ikan.

\section{Daftar Pustaka}

Anonim. 2016. The Seahorse Dilemma. Available: http://saveourseahorses.org/theseahorse-dilemma.php. (Januari 2016).

Apale, C. M., and A. Foster. 2016. The life history and ecology of seahorses in the Philippines. Draft Report in support of eventual CITES implementation for seahorses in the Philippines. Available : http://www.projectseahorse.org/ndf-countryspecific (Oktober 2010).

BP2KSI (Balai Penelitian Pemulihan dan Konservasi Sumberdaya Ikan). 2016. Ecological related species untuk kima (Tridacna spp.), bambu laut (Isis spp.) dan kuda laut (Hippocampus spp.). Laporan Tahunan Kegiatan, Balai Penelitian Pemulihan dan Konservasi Sumberdaya Ikan, Jatiluhur.
BPSPL (Balai Pengelolaan Sumber Daya Pesisir dan Laut) Padang. 2015. Pendataan potensi dan pemanfaatan kuda laut di Pulau Bintan. Balai Pengelolaan Sumber Daya Pesisir dan Laut Padang, Direktorat Jenderal Kelautan, Pesisir dan Pulau-Pulau Kecil, Kementerian Kelautan dan Perikanan, Padang.

Bruckner, A. W., J.D. Field, and N. Daves, editors. 2005. The proceeding of the international workshop on CITES Implementation for seahorse conservation and trade. NOAA Technical Memorandum NMFS-OPR-36, Silver Spring, MD.

Buzá-Jacobucci, G., and F. P. Pereira-Leite. 2014. The role of epiphytic algae and different species of Sargassum in the distribution and feeding of herbivorous amphipods. Latin American Journal of Aquatic Research 42(2): 353-363.

CITES (Convention on International Trade in Endangered Species of Wild Fauna and Flora). 2005. Trade in seahorses. Notification to the parties No 2005/014. Convention On International Trade In Endangered Species Of Wild Fauna And Flora.

Dermawan, A., N. N. Wiadnyana, dan S. Dodik, editor. 2015. Pedoman identifikasi dan monitoring populasi kuda laut. Direktorat Dirjen Konservasi dan Keanekaragaman Hayati Laut, Direktorat Jenderal Pengelolaan Ruang Laut, Kementerian Kelautan dan Perikanan, Jakarta. Effendie, M. I. 1997. Biologi perikanan. Penerbit Yayasan Pustaka Nusatama, Yogyakarta.

Freret-Meurer, N. V., and J. V. Andreata. 2008. Field studies of a Brazilian seahorse population, Hippocampus reidi Ginsburg, 1933. Brazilian Archives of Biology and Technology 51(4):543-551.

Freret-Meurer, N. V., T. Fernández, N. Okada, and A. Vaccan. 2018. Population dynamics of the endangered seahorse Hippocampus reidi Ginsburg, 1933 in a tropical rocky reef habitat. Animal Biodiversity and Conservation 41(2):345-356. 
Fianda, C., A. Pratomo, dan F. Idris. 2016. Identifikasi dan inventarisasi jenis kuda laut (Hippocampus sp.) yang hidup di perairan Pulau Bintan Provinsi kepulauan Riau. Program Studi Ilmu Kelautan, Universitas Maritim Raja Ali Haji. Tersedia : https://anzdoc.com/identifikasi-daninventarisasi-jenis-kuda-laut-hipocampussp.html (Februari 2016).

Foster, S. J., and A. C. J. Vincent. 2004. Life History and ecology of seahorses : implications for conservation and management. Journal of Fish Biology 665: 161.

Foster, S. J., and A. C. J. Vincent. 2005. Enhancing sustainability of the international trade in seahorses with a single minimum size limit. Conservation Biology 19(4):10441050.

IUCN (International Union for Conservation of Nature and Natural Resources). 2017. The IUCN red list of threatened species. Version 2017-2. Avalaible: www.iucnredlist.org. (Oktober 2017).

KLHK (Kementerian Lingkungan Hidup dan Kehutanan). 2015. Kuota Pengambilan Tumbuhan Alam dan Penangkapan Satwa Liar Periode Tahun 2015. Keputusan Direktur Jenderal Perlindungan Hutan dan Konservasi Alam No. SK.51/IV-SET/2015.

Kurniawan, A. 2016. Analisis kelimpahan populasi dan upaya pelestarian kuda laut (Hippocampus spp.) di perairan utara Pulau Bintan, Kepulauan Riau. Karya Ilmiah Praktik Akhir. Sekolah Tinggi Perikanan, Jakarta.

Lourie, S. A., A. C. Vincent, and H. J. Hall. 1999. Seahorses - an identification guide to the world's species and their conservation. Project Seahorse, London, United Kingdom.

Lourie, S. A. 2001. Seahorses (Genus Hippocampus) of Indonesia. Unpublished report, McGill University, Montreal, Canada.

Lourie, S.A., S. J. Foster, E. W. T. Cooper, and A. C. J. Vincent. 2004. A guide to the identification of seahorses. Project Seahorse and TRAFFIC North America. University of British Columbia and World Wildlife Fund, Washington D.C.

Martin-Smith, K. M., and A. C. Vincent. 2005. Seahorse declines in the Derwent Estuary, Tasmania in the absence of fishing pressure. Biological Conservation 123(4):533-545.

Mulyawan, A. E., dan J. Saokani. 2015. Karakteristik habitat dan kelimpahan kuda laut (Hippocampus barbouri) yang tertangkap di Kepulauan Tanakeke,
Kabupaten Takalar. Jurnal Balik Diwa 6(2):13-19.

Panama, N. 2016. Mendorong Pusat Selesaikan Pencemaran Limbah di Kepri. Tersedia: https://kepri.antaranews.com/berita/37593/m endorong-pusat-selesaikan-pencemaranlimbah-di-kepri. ( Februari 2019).

Sadili, D. 2015. Kuda Laut (Hippocampus spp.) dan Aspek Regulasinya. Tersedia: http://didisadili.blogspot.co.id/2015/06/kudalaut-hippocampus-spp-dan-aspek.html. (Januari 2016).

Santoso, B. 2014. Analisis jenis makanan kuda laut Hippocampus barbouri, (Jordan \& Richardson, 1908) pada daerah padang lamun di Kepulauan Tanakeke, Takalar, Sulawesi Selatan. Skripsi. Jurusan Ilmu Kelautan Fakultas Ilmu Kelautan dan Perikanan Universitas Hasanuddin, Makassar.

Sukmono, T. 2004. Studi perilaku kawin kuda laut (Hippocampus kuda) di Balai Budidaya Laut Lampung. Jurnal Iktiologi Indonesia 4(2): 67-70.

Syafiuddin. 2010. Studi aspek fisiologi reproduksi : perkembangan ovari dan pemijahan kuda laut (Hippocampus barbouri) dalam wadah budidaya. Disertasi. Sekolah Pascasarjana Institut Pertanian Bogor, Bogor.

Syafiuddin, A. M. I. Burhanuddin, dan Rastina. 2004. Studi potensi kuda laut Hippocampus barbouri pada daerah lamun di perairan Pulau Lantangpeo Kabupaten Takalar. Laporan Hibah Penelitian Program SP4. Jurusan Ilmu Kelautan, Fakultas Ilmu Kelautan dan Perikanan. Universitas Hasanuddin, Makassar.

Teixeira, R. L., and J. A. Musick. 2001. Reproduction and food habits of the lined seahorse, Hippocampus erectus (Teleostei: Syngnathidae) of Chesapeake Bay, Virginia. Revista Brasileira de Biologia 61(1):79-90.

Vincent, A.C.J., and L. M. Sadler. 1995. Faithful pair bonds in wild seahorses, Hippocampus whitei. Animal Behaviour, 50: 1557-1569.

Vincent, A. C. J. 1996. The international trade in seahorses. TRAFFIC International, Cambridge, United Kingdom.

Vicentini, R. N., and F. G. Araujo. 2003. Sex ratio and size structure of Micropogonias furnieri (Desmarest, 1823) (Perciformes, Sciaenidae) in Sepetiba Bay, Rio de Janeiro, Brazil. Brazilian Journal of Biology 63(4):559-566.

Wijayanti, H. M. 2007. Kajian kualitas perairan di pantai kota Bandar Lampung berdasarkan komunitas hewan makrobenthos. Tesis. Program Magister Manajemen Sumberdaya Pantai. Universitas Diponegoro, Semarang. 
Putri et al.

William, S. L., N. Janetski, J. Abbot, S. Blankenhorn, B. Cheng, R. E. Crafton, S. O. Hameed, S. Rapi, and D. Trockel. 2014. Ornamental marine species culture in the coral triangle : seahorse demonstration project in the Spermonde Islands, Sulawesi, Indonesia. Environmental Management 54(6): 1342-1355. 